\title{
Perspectives of Vegetable Grafting in Pakistan: Current Status, Challenges and Opportunities
}

\author{
Muhammad A. Nawaz ${ }^{1,2 *}$, Fareeha Shireen ${ }^{2}$, Yuan Huang ${ }^{2}$, Bie Zhilong2*, Waqar Ahmed ${ }^{3}$ and Basharat Ali Saleem ${ }^{4}$ \\ ${ }^{1}$ Department of Horticulture, University College of Agriculture, University of Sargodha, Sargodha, Pakistan \\ ${ }^{2}$ College of Horticulture and Forestry Sciences, Huazhong Agricultural University/Key Laboratory of Horticultural Plant \\ Biology, Ministry of Education, Wuhan, PR China \\ ${ }^{3}$ Sector Advisor (Horticulture), USAID-CNFA, Lahore, Pakistan \\ ${ }^{4}$ Department of Agriculture (Extension), Government of Punjab, Sargodha, Pakistan \\ *For correspondence: biezhilong@hotmail.com; azher490@hotmail.com
}

\begin{abstract}
In Pakistan vegetables are grown on fairly a large area and help to fulfill the food requirements of increasing population. The average yield of vegetables in Pakistan is lower compared with the other vegetables growing countries; several reasons contribute towards this low yield such as biotic factors (diseases and pest attack), abiotic factors (low and high temperature stress, high light intensity, water scarcity, and salinity), seed quality, and potential of local vegetable's cultivars. Vegetable grafting is commercially practiced in more than 28 countries across the world. According to the best of our knowledge, up till now there is no research work or practical application of vegetable grafting in Pakistan. Thus in this review we have tried to highlight the importance of vegetable grafting, and how this technique can help uplift/boost up the vegetable sector of Pakistan. Additionally, a working model has been suggested for the development of vegetable grafting in the country. In Pakistan, vegetables such as cucumber, melon, watermelon, tomato, pepper, and bell pepper are sown in plastic tunnels during winter (November and December) to get off season/early produce, however, because of low temperature during the early crop growth period (November-February), a slow rate of growth is observed. Grafting of these vegetable onto selected low temperature tolerant rootstocks can enhance the growth and productivity of vegetables. On the contrary, watermelon, muskmelon, tomato and chilies cultivated under field conditions during the summer season (March-September) suffer from higher temperatures and water scarcity. The use of appropriate rootstocks can enhance the heat and drought tolerance of these vegetables. In short, grafting can be utilized to overcome a large number of problems associated with vegetable production in Pakistan such as soil borne and foliar pathogens, nematodes attack, low and high temperatures stress, salt and heavy metals stress, drought and flooding stress. Additionally, grafting can improve the yield; prolong harvesting period and postharvest life of vegetables, provided appropriate rootstocks are utilized. Grafting of vegetables ensures limited use of inputs (pesticides and fertilizers), thus protects environment, promotes organic vegetable production; and it can help to uplift the economic status of farmers of Pakistan. (C) 2017 Friends Science Publishers
\end{abstract}

Keywords: Vegetable sector development; Seedling nurseries; Rootstock selection; Grafted transplants; Abiotic stress

\section{Introduction}

Sustainable agriculture is the first pillar of food security. According to the estimates of United Nations' Department of Economic and Social Affairs, by the year 2030, world have to feed 8.5 billion peoples. Agriculture sector meets the global food requirements, and known as single largest sector that provides jobs to $40 \%$ of the global workforce (FAO, 2014; UN, 2015). Likewise in other countries, agriculture is the dominating sector of Pakistan, providing food to the fast-growing population of the country. It contributes $19.8 \%$ to gross domestic product (GDP), employs $42.3 \%$ of the labour force, provides livelihood to $62 \%$ of the rural population, and contributes more than $66 \%$ to the export earnings (MOF, 2015-2016). The horticulture is an important subsector of agriculture that contributes $12 \%$ in the GDP of Pakistan (Akhtar et al., 2013). According to an estimate the country's horticulture export earnings exceeded 641 million dollars during 2015-2016. In addition to the agronomic crops, fruit and vegetables are cultivated on commercial scale and helps fulfill the dietary requirements of the increasing population of the country. Vegetables are considered as the protective food, being rich source of vitamins, minerals, dietary fiber (Sandeep et al., 2013), carbohydrates and proteins (Hameed et al., 2016). A large number of vegetables have been reported to possess substantial medicinal value and helps mitigate certain diseases; for example onion and garlic have antibacterial 
characteristics, Cucurbitaceae and Solanaceae vegetables contains vitamin $\mathrm{D}$ reserves and strengthen bones (FAO/WHO, 2004). In Pakistan, more than 30 different kinds of vegetables are grown on commercial scale (Hameed et al., 2016), the area, production, and yield of some important vegetables is provided in Table 1. Potato, tomato, onion, pepper, cabbage, cauliflower, spinach, cucumber, eggplant, okra, peas, carrot, turnips, pumpkin, bottle gourd, watermelon, and melons are the leading ones that are being utilized as cooked or raw.

Currently, the vegetable consumption in Pakistan is nearly 100 g per capita per day, while according to WHO recommendation this should be $400 \mathrm{~g}$ per capita per day (FAO/WHO, 2004). Similarly according to another report, nutritionists recommend a daily intake of $150 \mathrm{~g}$ of root vegetable and $250 \mathrm{~g}$ of leafy vegetables for effective nourishment (FAO, 1998). There are several reasons of this low consumption of vegetables that includes availability of vegetables and financial concerns. The yield of vegetables grown in Pakistan is lower compared with other vegetables producing countries (Table 2), for example the average yield of cucumber in Pakistan is 15.40 tons per ha and 42.10 , 48.19, 49.44, 60.95, 73.06, and 87.19 tons per ha in Mexico, China, Japan, Portugal, Greece, and Spain, respectively; and similar is the case with other vegetables such as watermelon, melons, eggplant and peppers. Interestingly in all these countries, vegetable grafting is widely adapted (Table 3) that seems one of the major reason of improved vegetables' yield (Lee et al., 2010; Bie et al., 2015, 2017). According to a recent report Bie et al. (2017) summarized that grafting improves the yield of melon (3-92\%), watermelon $(22-43 \%)$, cucumber $(9-57 \%)$, pepper $(9 \%)$, eggplant (28\%), tomato (5-80\%), and artichoke (22\%). Considering the importance and uses of vegetable grafting worldwide, this review article highlights the issues and challenges of vegetable industry of Pakistan, and how vegetable grafting can be utilized to solve those problems and trigger the vegetable sector of Pakistan. Additionally, a working model has been suggested for the development of vegetable grafting in Pakistan.

\section{Constraints in Vegetable Production of Pakistan}

Biotic factors: Among various factors contributing towards low average yield, biotic factors such as soil borne fungal diseases and pest attack (Nawaz et al., 2016a; Jiskani, 2017) are considered leading ones. Vegetable diseases such as root rot of eggplant, tomato, melon, watermelon, and cucumber (Farzana et al., 2016), collar rot of chilies (Naz et al., 2007) and other soil borne and foliar fungal diseases (Usman et al., 2014) reduce vegetables' yield in Pakistan. Nematodes also pose a serious threat to vegetables' production and considerably reduce the yield and quality of the produce (Anwar and McKenry, 2012; Shakeel et al., 2012).

Abiotic factors: Abiotic factors such as salinity (Khan, 2012; Ziad et al., 2016), low and high temperature stress
(Saeed et al., 2007), high light intensity, and water scarcity (Iqbal, 2010; Khan, 2014) are reported to reduce the yield and quality of vegetables crops. Khan (2012) reported that about 532,770 hectares of land is affected by salinity and sodicity in Pakistan. On these salt affected areas, either the crops cannot be grown, or if grown the yield and quality of produce is substantially compromised. Similarly, water shortage is another problem that affects the yield and quality of vegetable crops in Pakistan (Iqbal, 2010; Bajkani et al., 2013; Khan, 2014). With the passage of time, the problem of water scarcity is becoming more serious in Pakistan.

\section{Availability of Inputs}

The seed is the basic input of plant growth, development and yield. Seed quality and low potential of local cultivars is also a problem that contributes towards reduced crops yield (Bajkani et al., 2013, Raza, 2016). Additionally, the higher prices of inputs such as seed/hybrid seed, fertilizers and pest control products (fungicides and insecticides) limits the use of these products and results in production and quality losses of vegetable crops.

\section{Sewage Irrigation and Heavy Metal Stress}

In Pakistan, vegetables are produced in urban and peri-urban areas and sewerage water is utilized as a source of irrigation. Several studies conducted at different geographical locations of Pakistan (Lahore, Mardan, Gilgit Baltistan, Swabi, Khairpur, Sukkur, Hydrabad, Karachi) suggests that these vegetables contains exceptionally higher concentration of heavy metals such as $\mathrm{Cd}, \mathrm{Cu}, \mathrm{Cr}, \mathrm{Ni}, \mathrm{Co}, \mathrm{Ar}, \mathrm{Hg}$, and $\mathrm{Pb}$ and these metals pose serious health risks to the consumers (Jamali et al., 2007; Abbas et al., 2010; Khan et al., 2010a; Noor-ul-Amin et al., 2013; Mahmood and Malik, 2014). The constraints regarding vegetables' production are summarized in Table 4, and most of these problems can be minimized by the use of appropriate rootstocks.

\section{Opportunities}

To overcome the constraints faced by vegetable industry of Pakistan, selection and breeding of vegetable cultivars, use of hybrid seed (Raza, 2016), growing vegetables in plastic tunnels/greenhouses (Shaukat, 2014; Aazim, 2016; AARI, 2017), and exogenous application of plant growth regulators/bio-stimulators marketed by various pesticides and fertilizer companies are used. Recently the use of plant growth promoting rhizobacteria has been reported by some of the farmers to improve the growth of vegetable crops (personal communication). In technologically advanced countries arbuscular mycorrhizal fungi and the use of natural and synthetic chelators (Treeby et al., 1989; Bocanegra et al., 2006) are utilized to enhance the growth and productivity of agronomic and vegetable crops through improving the ion uptake. The details of those can be found 
Vegetable Grafting in Pakistan / Int. J. Agric. Biol., Vol. 19, No. 5, 2017

Table 1: Area and production of important vegetables produced in Pakistan (2014)

\begin{tabular}{|c|c|c|c|c|}
\hline Vegetable & Area (hectare) & Production (ton) & Yield (tones/hectare) & Reference \\
\hline Cabbages and other brassicas & 4,938 & 77,159 & 15.6256 & FAO, 2014 \\
\hline Carrots and turnips & 30,225 & 524,462 & 17.3519 & FAO, 2014 \\
\hline Cauliflowers and broccoli & 12,689 & 220,637 & 17.3881 & FAO, 2014 \\
\hline Chilies and peppers, dry & 62,742 & 145,856 & 2.3247 & FAO, 2014 \\
\hline Coriander & 5,297 & 2,868 & 0.54 & AMIS, 2014 \\
\hline Cucumbers and gherkins & 3,426 & 52,766 & 15.4016 & FAO, 2014 \\
\hline Eggplants (aubergines) & 8,325 & 82,999 & 9.9698 & FAO, 2014 \\
\hline Garlic & 7,430 & 64,473 & 8.6774 & FAO, 2014 \\
\hline Ginger & 282 & 126 & 0.4468 & FAO, 2014 \\
\hline Melons, and other cantaloupes & 18,607 & 227,002 & 12.1998 & FAO, 2014 \\
\hline Okra & 14,855 & 112,983 & 7.6057 & FAO, 2014 \\
\hline Onion & 133,922 & $1,740,184$ & 12.99 & AMIS, 2014 \\
\hline Peas & 44,858 & 28,204 & 0.63 & AMIS, 2014 \\
\hline Potato & 159,902 & $2,901,148$ & 18.14 & AMIS, 2014 \\
\hline Pumpkins, squash and gourds & 25,843 & 251,741 & 9.7412 & FAO, 2014 \\
\hline Spinach & 8,635 & 102,513 & 11.8718 & FAO, 2014 \\
\hline Sweet potatoes & 1,422 & 12,130 & 8.5302 & FAO, 2014 \\
\hline Tomato & 62,930 & 599,588 & 9.53 & AMIS, 2014 \\
\hline Turmeric & 5,281 & 67,807 & 12.84 & AMIS, 2014 \\
\hline Watermelons & 36,809 & 538,904 & 14.6405 & FAO, 2014 \\
\hline
\end{tabular}

Source: Food and Agricultural Organization (FAO, 2014); Agricultural Marketing and Information Service, Government of Punjab, Pakistan (AMIS, 2014)

Table 2: Comparison of yield (tons/ha) of different vegetables grown in various countries

\begin{tabular}{llllll}
\hline Country & Chilies & Eggplant & Melons & Watermelon & Cucumber \\
\hline Egypt & 3.09 & 25.30 & 27.98 & 28.77 & 22.70 \\
Greece & 4.43 & 23.14 & 17.63 & 43.32 & 73.06 \\
India & 1.92 & 19.06 & 22.35 & 14.07 & 6.34 \\
Mexico & 1.82 & 82.81 & 28.79 & 27.40 & 42.10 \\
Pakistan & 2.32 & 9.97 & 12.20 & 14.64 & 87.40 \\
Spain & 2.89 & 59.91 & 31.53 & 47.83 & 9.61 \\
Thailand & 3.69 & 32.59 & - & 21.14 & 26.98 \\
Turkey & 2.38 & 31.10 & 16.90 & 24.67 & 48.19 \\
China & 6.75 & 36.73 & 33.39 & 40.29 & 6.22 \\
Australia & - & - & 26.88 & 40.64 & 64.85 \\
Israel & - & 31.73 & 17.33 & 11.94 & 20.44 \\
Japan & - & 33.72 & 22.96 & 33.10 & 6.83 \\
Malaysia & 0.81 & - & - & 16.27 & 60.95 \\
Philippines & - & 10.66 & 9.24 & 18.74 & 32.89 \\
Portugal & - & 13.88 & 6.54 & 27.63 & 16.20 \\
UAE & - & 35.36 & 16.46 & 28.10 & \\
USA & - & 37.56 & 26.77 & 33.48 & \\
\hline
\end{tabular}

Source: Food and Agricultural Organization (FAO, 2014)

somewhere else and focus of this review is how vegetable grafting can be utilized as a tool to solve a large number of problems associated with the vegetable industry of Pakistan.

\section{History of Vegetable Grafting}

Grafting is an ancient technique; a Chinese book written in $1^{\text {st }}$ century BC and a Korean book in $17^{\text {th }}$ century reported that grafting was practiced to produce large sized gourd fruits (Lee and Oda, 2003). Some other grafting references available in the Bible, ancient Greek and Chinese literature suggests that grafting was practiced in the Asia, Europe, and the Middle East in the $5^{\text {th }}$ century BC (Melnyk and Meyerowitz, 2015). Grafting is utilized in fruits crops since the centuries however; its use is comparatively new in vegetable crops. The commercial vegetable grafting originated in the early $20^{\text {th }}$ century with an objective to control the soil-borne pathogens (Louws et al., 2010). On scientific grounds, vegetable grafting was launched for the first time in Korea and Japan in late 1920s by grafting watermelon onto gourd rootstocks to manage soil borne diseases (Ashita, 1927; Yamakawa, 1983), and this new technique was disseminated to the farmers by the agricultural extensions workers. During early 1930s commercial grafting of watermelon onto bottle gourd (Lagenaria siceraria (Mol.) Standl) and summer squash (Cucurbita moschata Duch.) was started to control Fusarium wilt (Oda, 2002; Sakata et al., 2007, 2008). In cucumbers, to reduce soil borne diseases and impart vigor to the scions, grafting is believed to be started in 1920 but was applied on commercial scale in 1960 (Fuji and Itagi, 1962; Sakata et al., 2008). As for as the Solanaceae crops are concerned, eggplant (Solanum melongena L.) was grafted onto scarlet eggplant (S. integrifolium Poir.) in 1950s (Oda, 
Table 3: The list of countries where grafted vegetables are produced/or cultivated on commercial scale

\begin{tabular}{lll}
\hline & \multicolumn{2}{c}{ Name of countries } \\
\hline China & Turkey & Belgium \\
Japan & Cyprus & Latvia \\
Korea & Bulgaria & Greece \\
Spain & Germany & Morocco \\
USA & Mexico & Argentina \\
Italy & Romania & Philippine \\
France & Croatia, & Egypt \\
The Netherlands & Bosnia & Iran \\
Canada & Herzegovina & Portugal \\
Israel & - & - \\
\hline Source: (Bie et al., 2017; Lee et al., 2010)
\end{tabular}

Source: (Bie et al., 2017; Lee et al., 2010)

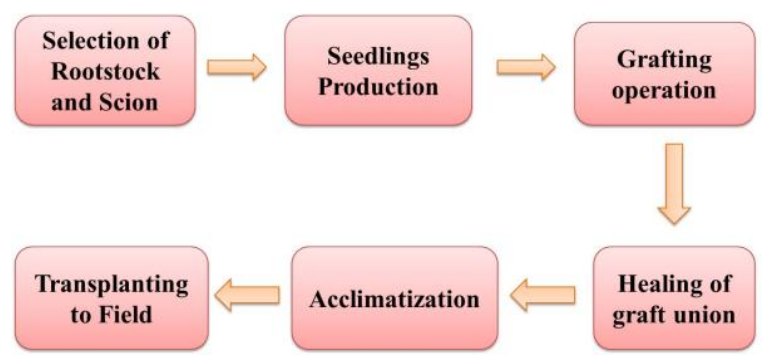

Fig 1: Summary of the steps involved in the production of grafted vegetable's transplants. (Modified from Bie et al., 2017)

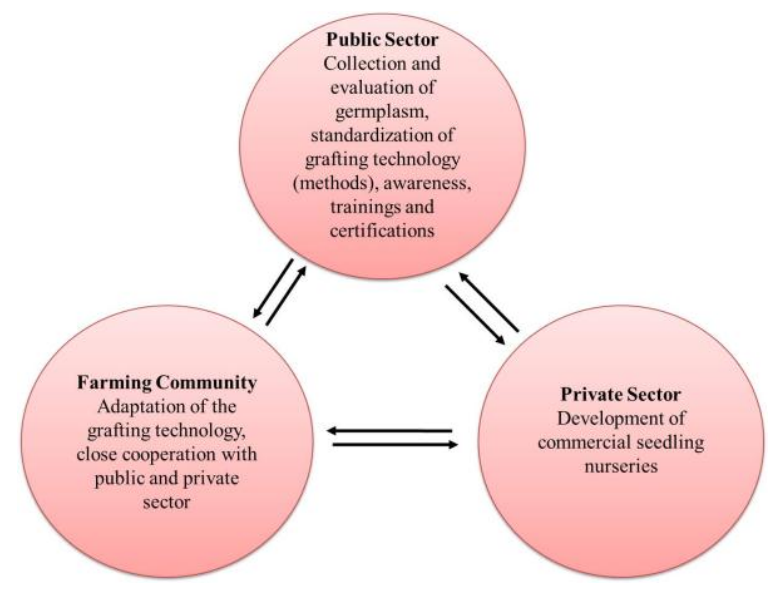

Fig. 2: A proposed working model for the development of vegetable grafting technology in Pakistan

1999), similarly grafting in tomato was started in 1960s (Lee and Oda, 2003). In 1950s, with the rapid development of protected cultivation (green houses and tunnel for off season vegetables production) farmers become dependent on grafting to control soil-borne and other pathogens (Kubota et al., 2008; Lee et al., 2010). The scientific work on screening and development of rootstock was started in 1960s in Korea (Kim, 1984). Up to 1990, the percentage of grafted transplants cultivation of Solanaceae and Cucurbitaceae vegetables increased up to 59\% in Japan and
$81 \%$ in Korea (Lee, 1994). Currently, most of the greenhouse-cultivated cucurbits are grafted in China, Japan, Korea, Turkey and Israel, and grafted vegetables being cultivated in more than 28 countries across the world (Table $3)$.

\section{Production of Grafted Transplants}

Grafting is practiced in Cucurbitaceae (watermelon, melons, cucumber, pumpkin, bitter gourd, squashes, and lufa) and Solanaceae (tomato, eggplant and peppers) vegetables. The production of grafted transplants include different steps such as selection of rootstock and scion cultivars, plantlet production, grafting operation (creation of physical union), healing of graft union, and acclimatization of grafted transplants (Lee et al., 2010; Bie et al., 2017) (Fig. 1). To produce grafted transplants of vegetables, the seeds of selected cultivars of rootstock and scions are sown in the seedling trays to produce plantlets. For most of the Cucurbitaceae vegetables grafting operation is practiced after the emergence of two true leaves of the rootstock while in Solanaceae vegetables grafting is practiced at four true leaves stage. In the grafting operation, the two parts of different plants (rootstock and scion) are joined together in a way that both grows together and make a new grafted transplant (Janick, 1986). For this purpose different grafting methods such as hole insertion grafting, tongue grafting, splice grafting, cleft grafting, and pin grafting are utilized (Lee et al., 2010, Bie et al., 2017). These days the mechanical grafting is also popular and grafting robots are utilized to perform the grafting operation in Korea, Japan, the Netherlands, Spain, and USA (Bie at al., 2017). The proper care of grafted transplants is necessary to get higher success ratio of the grafting process. Loss of moisture from the scion may lead towards the wilting and failure of graft union. Thus, during the first $48 \mathrm{~h}$ after grafting, transplants are placed at high humidity $(95 \%)$ and temperature is maintained at $27-28^{\circ} \mathrm{C}\left(82^{\circ} \mathrm{F}\right)$ (Bie at al., 2017). The use of various types of controlled environment (temperature and humidity) healing chambers enhance the graft union success ratio by up to $95 \%$ (Dong et al., 2015), and the use of these healing champers is widely practiced in Japan, Korea, China, Spain, and USA (Kawai et al., 1996; Lee et al., 1998; Bie et al., 2017). The details about the grafting methods, graft union healing and acclimatization process can be found in Bie et al. (2017).

\section{Benefits of Vegetable Grafting}

Vegetables grafting not only improves crops' yields and product quality (Huang et al., 2009; Rouphael et al., 2010), it is also utilized for enhancing plant vigor, tolerance to low and high temperatures (López-Marín et al., 2013), mitigating salinity and heavy metal stress (Schwarz et al., 2010; Huang et al., 2013a; Penella et al., 2015, 2016), improving endurance to drought and flooding stress 
Table 4: Constraints in vegetable's production sector of Pakistan and the potential of vegetable grafting to solve these constraints

\begin{tabular}{|c|c|}
\hline Constraints & Potential of vegetable grafting to solve the Constraint \\
\hline \multicolumn{2}{|l|}{ Abiotic } \\
\hline Salinity (Khan, 2012; Ziad et al., 2016) & Alleviate salt stress tolerance (Huang et al., 2013a; Penella et al., 2015, 2016) \\
\hline $\begin{array}{l}\text { Heavy metals stress (Jamali et al., 2007; Abbas et al., 2010; Khan et } \\
\text { al., 2010a; Noor-ul-Amin et al., 2013; Mahmood and Malik, 2014) }\end{array}$ & Improves heavy metals stress tolerance (Savvas et al., 2010) \\
\hline Water scarcity (Iqbal, 2010; Khan, 2014) & Enhances drought stress tolerance (Schwarz et al., 2010) \\
\hline Higher temperatures during summer season (Saeed et al., 2007) & Improves high temperature stress tolerance (Schwarz et al., 2010; López-Marín et al., 2013) \\
\hline Low temperatures during winter season & Improves low temperature stress tolerance (Lee et al., 2010; Bie at al., 2017) \\
\hline \multicolumn{2}{|l|}{ Biotic } \\
\hline $\begin{array}{l}\text { Soil born and foliar diseases of vegetables (Naz et al., 2007; Usman } \\
\text { et al., 2014; Farzana et al., 2016; Nawaz et al., 2016a; Jiskani, 2017) }\end{array}$ & $\begin{array}{l}\text { The diseases infestation can be minimized (Sakata et al., 2006; Gu et al., 2008; Louws et al., } \\
\text { 2010; Arwiyanto et al., 2015; Miles et al., 2015, Suchoff et al., 2015) }\end{array}$ \\
\hline Insects attack & No report available, needs investigations \\
\hline \multicolumn{2}{|l|}{ Other production related problems } \\
\hline Low yield (FAO, 2014, Hameed et al., 2016; Table 2) & $\begin{array}{l}\text { Increases yield of vegetables (Huang et al., 2009; Lee at al., 2010; Rouphael et al., 2010, Bie et } \\
\text { al., 2017) }\end{array}$ \\
\hline Reduced harvesting span & Can be prolonged (Lee et al., 2010; Bie et al., 2017) \\
\hline Postharvest life (Saeed \& Khan, 2010) & Improves postharvest life of vegetables (Zhao et al., 2011) \\
\hline
\end{tabular}

(Schwarz et al., 2010; Bhatt et al., 2015) and resistance to foliar pathogens (Louws et al., 2010; Arwiyanto et al., 2015; Miles et al., 2015, Suchoff et al., 2015), managing root knot nematodes (Lee et al., 2010), controlling weeds (Dor et al., 2010; Louws et al., 2010), prolonging the harvesting period (Lee et al., 2010), improving postharvest life (Zhao et al., 2011), and produce new plant species (tetraploids) (Fuentes et al., 2014). Similarly, grafting improves nutrient uptake and utilization efficiency in a number of vegetable crops (Pulgar et al., 2000; Zen et al., 2004; Lee et al., 2010; Huang et al., 2013b, Schwarz et al., 2013; Huang et al., 2016a, b, c; Nawaz et al., 2016b; Nawaz et al., 2017). According to a report, the economic analysis of tomato cultivation in Northern Florida showed that the net farm returns were increased by up to 630 USD to 6,151 USD per hectare in grafted tomatoes compared with nongrafted ones, and this increase was mainly attributed to the improved yield (Djidonou et al., 2013). According to another report, the cost benefit analysis showed that grafting can be utilized as an effective measure to control root knot nematodes (Meloidogyne sp.) for organic tomato production (Barrett et al., 2012).

\section{Current Status of Vegetable Grafting}

The statistics about the use of grafted transplants are difficult to obtain worldwide because of increasing trends and sometimes the data is not updated. The trend of grafted vegetable production varies country-wise, and even within the country. East Asia is the largest market for vegetable grafting because of high concentration of cucurbits and other grafted vegetables. For example in Korea, Japan, and China, 99\%, 94\% and 40\% of watermelon are produced through grafted transplants (Bie et al., 2017). In case of Solanaceae crops, about 60-65\% tomatoes and eggplants, and $10-14 \%$ peppers are produced through grafted transplants. Under protected cultivation systems such as greenhouses and tunnels, the ratio of grafted transplants is exceptionally higher and almost all cucumbers, watermelons, and tomato in Spain, Italy, Turkey and Israel are produced through grafted transplants. Similarly, in the Netherlands all the tomato under soilless culture conditions utilize grafted tomato transplants (Bie et al., 2017). In France, tomato and eggplants are particularly grafted to enhance resistance to soil borne pathogens and nematodes. Currently, vegetable grafting is expanding worldwide particularly in Eastern Europe, North and South America, India and Philippines. Some countries such as Canada and China have large-scale and well established nurseries that produce millions of grafted transplants annually. In China, over 1,500 commercial nurseries are producing grafted transplants. Some countries such as Canada export grafted transplants to Mexico, thus the international trading of grafted vegetable transplants is rapidly increasing (Bie et al., 2017). Grafting is widely used for fruit crops in Pakistan (Ahmed et al., 2006, 2007; Khan et al., 2010b); however, according to the best of our knowledge, for vegetable crops, grafting is not being practiced in the country, therefore present review article highlights the potential of vegetable grafting to solve the problems of vegetable industry of Pakistan.

\section{Applications of Vegetable Grafting Technique in Pakistan}

Considering the diverse applications of vegetable grafting worldwide, this technique has the potential to solve the problems of vegetable industry of Pakistan and can help boost farmer's income by improving the crops yield and reducing the cost incurred on purchase of huge amount of fertilizers and pest control products.

In Pakistan, the trend of protected vegetable cultivation is increasing. It is difficult to obtain the statistics about protected cultivation of vegetables in Pakistan, 
Nawaz et al. / Int. J. Agric. Biol., Vol. 19, No. 5, 2017

Table 5: Characteristics of some important rootstocks utilized for different vegetables

\begin{tabular}{|c|c|c|c|c|c|}
\hline Name of Scion & Name of Rootstock & Resistance to diseases & $\begin{array}{l}\text { Response to nutrient } \\
\text { availability in scion tissues }\end{array}$ & $\begin{array}{l}\text { Some other } \\
\text { characteristics }\end{array}$ & References \\
\hline \multirow{5}{*}{$\begin{array}{l}\text { Tomato } \\
\text { (Solanum } \\
\text { lycopersicum) }\end{array}$} & $\begin{array}{l}\text { Maxifort, He-Man }(S . \\
\text { lycopersicum L. } \times \text { S. habrochaites } \\
\text { S. Knapp and D. M. Spooner })\end{array}$ & $\begin{array}{l}\text { Resistance to bacterial wilt } \\
\text { and nematodes, multiple } \\
\text { disease resistance }\end{array}$ & $\begin{array}{l}\text { Improves availability of } \mathrm{N}, \mathrm{P} \text {, } \\
\mathrm{Ca}, \mathrm{Mg}, \mathrm{Mn}, \mathrm{Zn}, \mathrm{B}, \mathrm{Fe} \text { and } \\
\text { Cu to the scion }\end{array}$ & Salt tolerant & $\begin{array}{l}\text { Savvas et al., 2009; Colla } \\
\text { et al., 2010; Borgognone } \\
\text { et al., } 2013\end{array}$ \\
\hline & Solanum torvum & Disease resistant & $\begin{array}{l}\text { Improves nutrients } \\
\text { availability to the scion }\end{array}$ & $\begin{array}{l}\text { Nematode tolerant, good } \\
\text { vigor, no negative impact } \\
\text { on fruit quality, salt tolerant }\end{array}$ & $\begin{array}{l}\text { Colla } \text { et al., 2010; Lee } e t \\
\text { al., } 2010\end{array}$ \\
\hline & $\begin{array}{l}\text { AR-9704 Tomato (Solanum } \\
\text { lycopersicum L.) }\end{array}$ & - & $\begin{array}{l}\text { Improves availability of } \mathrm{P} \text {, } \\
\text { and } \mathrm{S} \text { while, reduces uptake } \\
\text { and transport of } \mathrm{Na} \text { and } \mathrm{Cl} \text { to } \\
\text { the scion }\end{array}$ & Salt tolerant & $\begin{array}{l}\text { Fernández-García et al., } \\
\text { 2002; Colla et al., } 2010\end{array}$ \\
\hline & $\begin{array}{l}\text { Solanum lycopersicum cv. } \\
\text { Tmknvf } 2\end{array}$ & - & $\begin{array}{l}\text { Improves availability of } \mathrm{Fe} \\
\text { to the scion }\end{array}$ & Salt tolerant & $\begin{array}{l}\text { Rivero et al., 2004; Colla } \\
\text { et al., } 2010\end{array}$ \\
\hline & $\begin{array}{l}\text { Solanum lycopersicum Mill. cv. } \\
\text { Radja }\end{array}$ & - & $\begin{array}{l}\text { Improves availability of } \mathrm{K} \text { to } \\
\text { the scion }\end{array}$ & Salt tolerant & $\begin{array}{l}\text { Estan et al., 2005; Colla } \text { et } \\
\text { al., } 2010\end{array}$ \\
\hline $\begin{array}{l}\text { Chilies } \\
\text { Capsicum annum }\end{array}$ & $\begin{array}{l}\text { Capsicum annuum L. } \times \text { Capsicum } \\
\text { chinensis Jacq }\end{array}$ & - & $\begin{array}{l}\text { Improves availability of } \mathrm{K} \text { to } \\
\text { the scion }\end{array}$ & $\begin{array}{l}\text { Superior growth and } \\
\text { yield }\end{array}$ & Lee et al., 2010 \\
\hline \multirow{4}{*}{$\begin{array}{l}\text { Eggplant } \\
\text { (Solanum } \\
\text { melongena) }\end{array}$} & Solanum torvum & Disease resistant & $\begin{array}{l}\text { Improves nutrients } \\
\text { availability to the scion }\end{array}$ & $\begin{array}{l}\text { Nematode resistant, good } \\
\text { vigor, salt tolerant }\end{array}$ & $\begin{array}{l}\text { Colla } \text { et al., 2010; Lee } e t \\
\text { al., } 2010\end{array}$ \\
\hline & $\begin{array}{l}\text { S. torvum } S w . \times S \text {. sanitwongsei } \\
\text { Craib }\end{array}$ & Resistance to bacterial wilt & $\begin{array}{l}\text { Improves nutrients } \\
\text { availability to the scion }\end{array}$ & $\begin{array}{l}\text { Nematode resistant, good } \\
\text { vigor, salt tolerant }\end{array}$ & $\begin{array}{l}\text { Colla et al., 2010; Lee } \text { et } \\
\text { al., } 2010\end{array}$ \\
\hline & Hongdun (Citrullus lanatus Sp.) & - & $\begin{array}{l}\text { Improves availability of } \mathrm{K} \text { to } \\
\text { the scion }\end{array}$ & - & $\begin{array}{l}\text { Lee } \text { et al., 2010; Huang et } \\
\text { al., 2013b }\end{array}$ \\
\hline & $\begin{array}{l}\text { Jingxinzhen No.4 (Cucurbita } \\
\text { moschata Duch.) }\end{array}$ & Fusarium tolerance & $\begin{array}{l}\text { Improves availability of } \mathrm{Mg} \\
\text { to the scion }\end{array}$ & $\begin{array}{l}\text { Low temperature } \\
\text { tolerant, vigorous root } \\
\text { system, salt tolerant }\end{array}$ & $\begin{array}{l}\text { Colla et al., 2010; Lee } \text { et } \\
\text { al., 2010; Huang et al., } \\
2016 \mathrm{~b}\end{array}$ \\
\hline \multirow[t]{3}{*}{$\begin{array}{l}\text { Watermelon } \\
\text { (Citrullus } \\
\text { lanatus) }\end{array}$} & $\begin{array}{l}\text { Ferro, RS841 (Cucurbita } \\
\text { maxima } \times \text { C. moschata) }\end{array}$ & Fusarium tolerance & $\begin{array}{l}\text { Improves availability of } \mathrm{N}, \\
\mathrm{Ca}, \mathrm{K}, \mathrm{Mg} \text { to the scion }\end{array}$ & $\begin{array}{l}\text { Low and high } \\
\text { temperature tolerant, } \\
\text { vigorous root system, salt } \\
\text { tolerant }\end{array}$ & $\begin{array}{l}\text { Colla et al., 2010; Lee et } \\
\text { al., 2010; Yetisir } \text { et al., } \\
2013\end{array}$ \\
\hline & $\begin{array}{l}\text { Cucubirta maxima var. Dulce } \\
\text { maravilla }\end{array}$ & Fusarium tolerance & $\begin{array}{l}\text { Improves availability of } \mathrm{Fe} \\
\text { to the scion }\end{array}$ & $\begin{array}{l}\text { Low temperature } \\
\text { tolerant, vigorous root } \\
\text { system, salt tolerant }\end{array}$ & $\begin{array}{l}\text { Rivero et al., 2004; Colla } \\
\text { et al., 2010; Lee et al., } \\
2010\end{array}$ \\
\hline & $\begin{array}{l}\text { Keumsakwa, Unyong, Super } \\
\text { Unyong (Cucubirta pepo) }\end{array}$ & Fusarium tolerance & $\begin{array}{l}\text { Improves nutrients } \\
\text { availability to the scion }\end{array}$ & $\begin{array}{l}\text { Low temperature } \\
\text { tolerant, vigorous root } \\
\text { system }\end{array}$ & Lee et al., 2010 \\
\hline \multirow{4}{*}{$\begin{array}{l}\text { Melon } \\
\text { (Cucumis melo) }\end{array}$} & $\begin{array}{l}\text { FR Dantos, Partner, Renshi, FR } \\
\text { Combi, TanTan (Lagenaria } \\
\text { siceraria) }\end{array}$ & Fusarium tolerance & $\begin{array}{l}\text { Improves nutrients } \\
\text { availability to the scion }\end{array}$ & $\begin{array}{l}\text { Vigorous root system, } \\
\text { salt tolerant, }\end{array}$ & Lee and Oda, 2003 \\
\hline & $\begin{array}{l}\text { C. maxima } \times \text { C. moschata } \\
\text { (Shintoza, RS- } 841, \text { and Kamel) }\end{array}$ & Fusarium tolerance & $\begin{array}{l}\text { Improves availability of } \mathrm{N}, \mathrm{P} \text {, } \\
\mathrm{Ca}, \mathrm{K}, \mathrm{Mg}, \mathrm{Mn} \text {, and } \mathrm{Zn} \text { to } \\
\text { the scion. Reduces uptake } \\
\text { and transport of } \mathrm{Na} \text { and } \\
\text { heavy metals to the scion }\end{array}$ & $\begin{array}{l}\text { Low and high } \\
\text { temperature tolerant, } \\
\text { vigorous root system, salt } \\
\text { tolerant }\end{array}$ & $\begin{array}{l}\text { Ruiz et al., 1997; Colla } \text { et } \\
\text { al., 2010; Lee et al., 2010; } \\
\text { Bautista } \text { et al., 2011; } \\
\text { Salehi } \text { et al., } 2014\end{array}$ \\
\hline & $\begin{array}{l}\text { Keumsakwa, Unyong, Super } \\
\text { Unyong (Cucubirta pepo) }\end{array}$ & Fusarium tolerance & $\begin{array}{l}\text { Improves nutrients } \\
\text { availability to the scion }\end{array}$ & $\begin{array}{l}\text { Low and high } \\
\text { temperature tolerant, } \\
\text { vigorous root system, } \\
\text { flooding tolerant }\end{array}$ & Lee et al., 2010 \\
\hline & $\begin{array}{l}\text { Rootstock \#1, Kangyoung, } \\
\text { Keonkak, Keumgang } \\
\text { (Cucumis melo) }\end{array}$ & Fusarium tolerance & - & Improves fruit quality & Lee et al., 2010 \\
\hline \multirow{3}{*}{$\begin{array}{l}\text { Cucumber } \\
\text { (Cucumis } \\
\text { sativus) }\end{array}$} & $\begin{array}{l}\text { Heukjong (black seeded figleaf } \\
\text { gourd) (Cucurbita ficifolia } \\
\text { Bouché) }\end{array}$ & $\begin{array}{l}\text { Good disease resistance } \\
\text { against soil borne } \\
\text { pathogens and downy } \\
\text { mildew }\end{array}$ & $\begin{array}{l}\text { Improves nutrients } \\
\text { availability to the scion }\end{array}$ & $\begin{array}{l}\text { Low temperature } \\
\text { tolerance, vigorous root } \\
\text { system, salt tolerant }\end{array}$ & $\begin{array}{l}\text { Gu et al., 2008; Colla et } \\
\text { al., 2010; Lee } \text { et al., } 2010\end{array}$ \\
\hline & $\begin{array}{l}\text { Butternut, Unyong \#1, Super } \\
\text { Unyong, PPMR-1 (Cucurbita } \\
\text { moschata Duch.) }\end{array}$ & $\begin{array}{l}\text { Fusarium tolerance, } \\
\text { powdery mildew }\end{array}$ & - & $\begin{array}{l}\text { Improves fruit quality, } \\
\text { salt tolerant }\end{array}$ & $\begin{array}{l}\text { Sakata et al., 2006; Colla } \\
\text { et al., 2010; Lee et al., } \\
2010\end{array}$ \\
\hline & $\begin{array}{l}\text { Shintozwa, Keumtozwa, Ferro } \\
\text { RZ, 64-05 RZ, Gangryuk Shinwha } \\
(\text { C. maxima } \times \text { C. moschata })\end{array}$ & $\begin{array}{l}\text { Fusarium tolerance, } \\
\text { powdery mildew }\end{array}$ & $\begin{array}{l}\text { Improves nutrients } \\
\text { availability to the scion }\end{array}$ & $\begin{array}{l}\text { Low temperature } \\
\text { tolerance, vigorous root } \\
\text { system, salt tolerant }\end{array}$ & $\begin{array}{l}\text { Sakata et al., 2006; Colla } \\
\text { et al., 2010; Lee } \text { et al., } \\
2010\end{array}$ \\
\hline
\end{tabular}

according to a report it covers an area of over 18,000 ha only in Punjab province, and an increasing trend has been observed during the last two decades (AARI, 2017). The growth rate of protected cultivation system has been estimated 25-40\% in Punjab province, and 10\% in Sindh and Khyber Pakhtunkhwa provinces (Shaukat, 2014).
According to another report, the area under protected cultivation is very high, that is estimated around 100,000 to 120,000 ha and most of this lies in Punjab province (Aazim, 2016). In protected cultivation system, sowing of some summer vegetable such as cucumber, melon, watermelon, tomato, pepper, and bell pepper is practiced in winter 
(November-December) to get off season/early crops to maximize economic returns. Low temperatures, during the early crop growth period (November-February) reduces rate of growth. Grafting of these vegetable onto selected low temperature rootstocks (Table 5) can enhance the growth and productivity of these vegetables. Similarly, most of the watermelon, muskmelon, tomato, and chilies are also cultivated under field conditions during summer season (March-September) that suffer from higher temperature and water scarcity. The use of appropriate rootstocks can enhance the heat and drought tolerance of these vegetables. Similarly, other problems such as soil borne and foliar pathogens, nematodes attack, low and high temperatures stress, salt and heavy metals stress, drought and flooding stress can also be minimized. Moreover, grafting improves the yield, harvesting period and postharvest life of vegetables; provided, appropriate rootstocks are utilized. Some recent development such as the installation of greenhouses and hydroponic cultivation systems by public and private sector in Pakistan further necessitates the adoption of vegetable grafting technique. To get benefit from vegetable grafting technology, the screening and selection of compatible and appropriate rootstock for a specific problem is very important that need attention of plant biologists working in public and private sector of Pakistan.

\section{Conceptual Framework for the Development of Vegetable Grafting in Pakistan}

As vegetable grafting is not practiced in Pakistan, following working model has been devised for its development: 1) The research and development organizations should collect the germplasm (cultivated and wild) of different rootstock cultivars of graftable-vegetables (melons, watermelon, cucumber, tomato, bitter gourd, eggplant and peppers) and test their graft-compatibility with locally adapted commercially cultivated scion cultivars. The adaptability of rootstocks to local soil and environmental conditions should also be investigated, and then some better performing disease resistant and nutrient efficient rootstocks should be selected for each vegetable. The list of some important rootstocks utilized in different countries along with their characteristics is provided in Table 5; which may serve as a reference for initial selection and start of rootstocks screening studies in Pakistan. The detailed information of rootstocks responses to different diseases, biotic and abiotic stresses, nutrient availability, and rootstock to scion compatibility can be found in previously published reviews (Lee, 1994; Lee and Oda, 2003; Davis et al., 2008; Lee et al., 2010; Louws et al., 2010, Savvas et al., 2010; Nawaz et al., 2016b; Bie et al., 2017). 2) Public and private sector involved in vegetable research and development may import the rootstock and scion cultivars from other countries (China, Korea, Japan, Spain), test their adaptability to local conditions and get those cultivars registered with provincial or federal seed certification departments. 3) Different methods of grafting should be tested and best methods should be finally selected for further utilization and commercialization in Pakistan. The details about the production process of grafted transplants, grafting methods, and post-graft healing requirements are discussed in detail by Lee et al. (2010), and Bie et al. (2017). 4) The benefitcost analysis should be performed by the researchers and the results should be shared with the stakeholders to attract the farming community to adopt this technology. 5) Mass awareness campaigns and farmer trainings about vegetable grafting technology may help in adapting this eco-friendly technology on large scale (Fig. 2). 6) The government of Pakistan particularly funding agencies such as Ministry of Science and Technology (MoST), Pakistan Agricultural Research Council (PARC), Higher Education Commission of Pakistan (HEC), Punjab Agricultural Research Board (PARB), Pakistan Science Foundation (PSF), and Pakistan Council for Science and Technology (PCST) have to play a leading role by providing funds to conduct research and development work on vegetable grafting technology in Pakistan. For example "Fruit and Vegetable Development Project" was launched by Government of Punjab, which helped to raise the area and production of fruit and vegetables across the province. Similarly, during the last few years, Government of Punjab, through Department of Agricultural Extension, is supporting the vegetable growers by providing subsidy on the installation of tunnels to enhance the area under protected cultivation of vegetables.

\section{Conclusion and Future Perspectives}

Vegetable grafting is a viable technique that can be utilized to alleviate biotic and abiotic stresses leading towards improved productivity and economic returns. Grafting is an eco-friendly technology, because this helps to reduce the use of pesticides and fertilizers in vegetable production and thus promotes organic vegetable production. Grafting vegetables onto selected rootstocks can obviously reduce the heavy metal contents in the scion tissues (Savvas et al., 2010, 2013; Xin et al., 2013; Nawaz et al., 2016b; Zhou et al., 2016) and help to reduce the health hazards. Soilless culture is getting popularity in Pakistan; vegetable grafting can further enhance the benefits and usefulness of this technique. Additionally, the adoption of vegetable grafting at commercial level creates a lot of job opportunities for the workers, because of high labour requirements for the grafting operation and other associated tasks such as seedlings production and after care, and transport and transplanting practices. In the international market the trading of grafted transplants is increasing rapidly, with the development of grafted vegetable industry in Pakistan this option can be availed to earn foreign exchange; because the labor costs are lower in Pakistan compared with other countries producing grafted vegetable transplants. 


\section{References}

AARI, 2017. Ayyub Agricultural Research Institute, Government of Punjab, Pakistan. http://www.aari.punjab.gov.pk/farmer-services/forfarmers/tunnel-gardening (Accessed on January 24, 2017)

Aazim, M., 2016. Tunnel farming gains ground. Dawn. November 21, 2016. http://www.dawn.com/news/1297525 (Accessed on January, 2017)

Abbas, M., Z. Parveen, M. Iqbal, Riazuddin, S. Iqbal, M. Ahmed and R. Bhutto, 2010. Monitoring of toxic metals (cadmium, lead, arsenic and mercury) in vegetables of Sindh, Pakistan. Kathmandu Uni. J. Sci. Eng. Technol., 6: 60-65

Ahmed, W., M.A. Nawaz, M.A. Iqbal and M.M. Khan, 2007. Effect of different rootstocks on plant nutrient Status and yield in Kinnow mandarin (Citrus reticulate Blanco). Pak. J. Bot., 39: 1779-1786

Ahmed, W., M.A. Pervez, M. Amjad, M. Khalid, C.M. Ayyub, and M.A. Nawaz, 2006. Effect of stionic combination on the growth and yield of Kinnow mandarin (Citrus reticulata Blanco). Pak. J. Bot., 38: 603-612

Akhtar, W., N. Akmal, H. Shah, M.A. Niazi and A. Tahir, 2013. Export competitiveness of Pakistani horticultural products. Pak. J. Agric. Res., 26: 87-96

AMIS, 2014. Agriculture Marketing and Information Service, Agriculture Department, Government of Punjab, Pakistan. www.amis.pk (Accessed on September 22, 2016)

Anwar, S.A. and M.V. McKenry, 2012. Incidence and population density of plant-parasitic nematodes infecting vegetables crops and associated yield losses in Punjab, Pakistan. Pak. J. Zool., 44: 327-333

Arwiyanto, T., K. Lwin, Y. Maryudani and A. Purwantoro, 2015. Evaluation of local Solanum torvum as a rootstock to control of Ralstonia solanacearum in Indonesia. In: Proceeding of the First International Symposium on Vegetable Grafting Z. Bie, Y. Huang, M.A. Nawaz (eds.). Acta Hort., 1086: 101-106

Ashita, E., 1927. Grafting of Watermelons Korea. Chosun (ed.). Agricultural Newsletter 1, 9

Bajkani, J.K., K. Ahmed, M. Afzal, N. Sadiq and M.N. Irshad, 2013. Economic analysis "cost of production of major vegetables" in Balochistan, Pakistan. IOSR J. Agric. Vet. Sci., 6: 12-19

Barrett, C.E., X. Zhao and A.W. Hodges, 2012. Cost benefit analysis of using grafted transplants for root-knot nematode management in organic heirloom tomato production. Hort. Technol., 22: 252-257

Bautista, A.S., A. Calatayud, S.G. Nebauer, B. Pascual, J.V. Maroto and S. Lopez-Galarza, 2011. Effects of simple and double grafting melon plants on mineral absorption, photosynthesis, biomass and yield. $S \mathrm{Ci}$. Hortic., 130: 575-580

Bhatt, R.M., K.K. Upreti, M.H. Divya, S. Bhat, C.B. Pavithra and A.T. Sadashiva, 2015. Interspecific grafting to enhance physiological resilience to flooding stress in tomato (Solanum lycopersicum L.). Sci. Hortic., 182: 8-17

Bie, Z., M.A. Nawaz, Y. Huang, J.M. Lee and G. Colla, 2017. Introduction of vegetable grafting. In: Vegetable Grafting, Principles and Practices. Colla, G., F.P. Alfocea and D. Schwarz (eds.). CABI Publishing, UK

Bie, Z., Y. Huang and M.A. Nawaz, 2015. Proceedings of the first International symposium on vegetable grafting held at Huazhong Agricultural University, Wuhan, China. ISHS Acta Horticulturae 1086. Int. Soc. Hort. Sci., pp: 1-291

Bocanegra, M.P., J.C. Lobartini and G.A. Orioli, 2006. Plant uptake of iron chelated by humic acids of different molecular weights. Commun. Soil Sci. Plant Anal., 37: 239-248

Borgognone, D., G. Colla, Y. Rouphael, M. Cardarelli, E. Reac and D. Schwarzd, 2013. Effect of nitrogen form and nutrient solution $\mathrm{pH}$ on growth and mineral composition of self-grafted and grafted tomatoes. Sci. Hortic., 149: 61-69

Colla, G., Y. Rouphael, C. Leonardi and Z. Bie, 2010. Role of grafting in vegetable crops grown under saline conditions. Sci. Hortic., 127: $147-155$

Davis, A.R., P. Perkins-Veazie, Y. Sakata, S. López-Galarza, J.V. Maroto, S.G. Lee, Y.C. Huh, Z. Sun, A. Miguel, S.R. King, R. Cohen and J.M. Lee, 2008. Cucurbit grafting. Crit. Rev. Plant Sci., 27: 50-74
Djidonou, D., Z. Gao and X. Zhao, 2013. Economic analysis of grafted tomato production in sandy soils in northern Florida. HortTechnology, 23: 613-621

Dong, W., Z.C Zhou, Y.L Bu, J.Q. Zhuo, L.Z. Chen and Y.Z. Li, 2015. Research and application of grafted seedlings healing room. Acto Hort., 1086: 51-57

Dor, E., B. Alperin, S. Wininger, B. Ben-Dor, V.S. Somvanshi, H. Koltai, Y. Kapulnik and J. Hershenhorn, 2010. Characterization of a novel tomato mutant resistant to the weedy parasites Orobanche and Phelipanche spp. Euphytica, 171: 371-380

Estan, M.T, M.M. Martinez-Rodriguez, F. Pérez-Alfocea, T.J. Flowers and M.C. Bolarin, 2005. Grafting raises the salt tolerance of tomato through limiting the concentration of sodium and chloride to the shoot. J. Exp. Bot., 56: 703-712

FAO, 1998. Report of Regional Expert Consultation on Asian Network for Food and Nutrition. Bangkok

FAO, 2014. Food and Agricultural Organization of the United Nations. http://www.fao.org/faostat/en/\#data/QC (Accessed on January 25, 2017)

FAO/WHO, 2004. Workshop on Fruit and Vegetables for Health, Kobe, Japan. Fruit and vegetables for health: Report of a Joint FAO/WHO Workshop. September 1-3, 2004, Kobe, Japan. http://www.who.int/dietphysicalactivity/publicati ons/fruit_vegetables_report.pdf (Accessed on Januray 20, 2017)

Farzana, M. Abid and F. Hussain, 2016. Root-rot and root knot disease complex of vegetables in Karachi region and their non-chemical control. Int. J. Biol. Biotechnol., 13: 143-151

Usman, F., M. Abid, F. Hussain, S.A. Khan and J. Sultana, 2014. Soil borne fungi associated with different vegetable crops in Sindh, Pakistan. Pak. J. Sci. Ind. Res. Ser. Biol. Sci., 57: 140-147

Fernández-García, N., V. Martínez, A. Cerdá and M. Carvajal, 2002. Water and nutrient uptake of grafted tomato plants grown under saline conditions. J. Plant Physiol., 159: 899-905

Fuentes, I., S. Stegemann, H. Golczyk, D. Karcher and R. Bock, 2014. Horizontal genome transfer as an asexual path to the formation of new species. Nature, 511: 232-235

Fuji, T. and T. Itagi, 1962. Cucumber. In: Vegetable Production Technology. Seibundo-Shinkosha, Tokyo, Japan

Gu, J.T., S.X. Fan and X.C Zhang, 2008. Effects of rootstocks on the development, disease resistance and quality of Cucumis sativus $\mathrm{L}$. Acta Hort., 771: 161-166

Hameed, S., M.A. Nawaz, W. Ahmed, A. Shehzadi, F. Hussain, N. Munir, M.N. Khan and F. Hayat, 2016. Potential of horticultural crops to ensure food security in Pakistan. J. Environ. Agric., 1: 74-78

Huang, Y., J. Li, B. Hua, Z. Liu, M. Fan and Z. Bie, 2013b. Grafting onto different rootstocks as a means to improve watermelon tolerance to low potassium stress. Sci. Hortic., 149: 80-85

Huang, Y., L. Zhao, Q. Kong, F. Cheng, N. Mengliang, X. Junjun, M.A. Nawaz and Z. Bie, 2016a. Comprehensive mineral nutrition analysis of watermelon grafted onto two different rootstocks. Hort. Plant J., 2: $105-113$

Huang, Y., R. Tang, Q. Cao and Z. Bie, 2009. Improving the fruit yield and quality of cucumber by grafting onto the salt tolerant rootstock under $\mathrm{NaCl}$ stress. Sci. Hortic., 122: 26-31

Huang, Y., Y. Jiao, M.A. Nawaz, C. Chen, L. Liu, Z. Lu, Q. Kong, F. Cheng and $\mathrm{Z}$. Bie, 2016b. Improving magnesium uptake, photosynthesis and antioxidant enzyme activities of watermelon by grafting onto pumpkin rootstock under low magnesium. Plant Soil, 409: 229-246

Huang, Y., Y. Jiao, M.A. Nawaz, C. Chen, Y. Zhong, F. Cheng, Q. Kong and Z. Bie, 2016c. Rootstock grafting improves fruit yield and quality of watermelon through enhancing the uptake of potassium under low potassium. The Second Asian Horticultural Congress. September 26-28, 2016 held at Chengdu, China, p: 29

Huang, Y., Z. Bie, P. Liu, M. Niu, A. Zhen, Z. Liu, B. Lei, D. Gu, C. Lu and B. Wang, 2013a. Reciprocal grafting between cucumber and pumpkin demonstrates the roles of the rootstock in the determination of cucumber salt tolerance and sodium accumulation. Sci. Hortic., 149: 47-54 
Iqbal, A.R, 2010. Water Shortage in Pakistan a Crisis Around the Corner. ISSRA Papers. Available at: http://www.ndu.edu.pk/issra/issra_pub/articles/issrapaper/ISSRA_Papers_Vol2_IssueII_2010/01-Water-Shortage-inPakistan-Abdul-Rauf-Iqbal.pdf. (Accessed: $23^{\text {rd }}$ May, 2017)

Jamali, M.K., T.G. Kazi, M.B. Arain, H.I. Afridi, N. Jalbani and A.R. Memon, 2007. Heavy metal contents of vegetables grown in soil, irrigated with mixtures of wastewater and sewage sludge in Pakistan, using ultrasonic-assisted pseudo-digestion. J. Agron. Crop Sci., 193: 218-228

Janick, J., 1986. Horticultural Science, $4^{\text {th }}$ edition. W.H. Freeman and Co., New York, USA

Jiskani, M.M., 2017. Wilt: The Most Common and Destructive Disease of Crops.

http://www.pakissan.com/english/advisory/wilt.the.most.common.an d.destructive.disease.of.crops.shtml (Accessed on January 25, 2017)

Kawai, J., N. Onouti, K. Niwa and T. Ito, 1996. The development of grafts for seedlings raised in cellular pots and simple acclimating equipment in tomato plants. Aichi Agricultural Research Center, Japan. Res. Bull., 28: 149-155

Khan, J.A., 2012. Soil Survey in Pakistan, History, Achievement and Impact on Agriculture.Soil Survey of Punjab, Pakistan (Accessed April 25, 2017) http://www.fao.org/fileadmin/user_upload/GSP/docs/Presentation_chi na_feb2012/Khan.pdf

Khan, M.N., M.A. Nawaz, W. Ahmad, M. Afzal, A.U. Malik and B.A. Saleem, 2010b. Evaluation of some exotic cultivars of sweet orange in Punjab, Pakistan. Int. J. Agric. Biol., 12: 729-733

Khan, S., S. Rehman, A.Z. Khan, M.A. Khan and M.T. Shah, 2010a. Soil and vegetables enrichment with heavy metals from geological sources in Gilgit, northern Pakistan. Ecotoxicol. Environ. Saf., 73: $1820-1827$

Khan, T.H., 2014. Water scarcity and its impact on agriculture Case study of Layyah, Pakistan. Master's Thesis, Swedish University of Agricultural Sciences, SLU, Uppsala, Sweden

Kim, J.H., 1984. The History of Horticulture Development in Korea, pp: 157-260. Seoul National University Press, Seoul, Korea

Kubota, C., M.A. McClure, N. Kokalis-Burelle, M.G. Bausher and E.N. Rosskopf, 2008. Vegetable grafting: history, use, and current technology status in North America. HortScience, 43: 1164-1669

Lee, J.M. and M. Oda, 2003. Grafting of herbaceous vegetable and ornamental crops. In: Horticultural Reviews, Vol. 28, pp: 61-124. Janick, J. (ed.). John Wiley and Sons, New York, USA

Lee, J.M., 1994. Cultivation of grafted vegetables. I. Current status, grafting methods, and benefits. HortScience, 29: 235-239

Lee, J.M., C. Kubota, S.J. Tsao, Z. Bie, P.H. Echevarria, L. Morra and M. Oda, 2010. Current status of vegetable grafting: diffusion, grafting techniques, automation. Sci. Hortic., 127: 93-105

Lee, J.M., H.J. Bang and H.S. Ham, 1998. Grafting of vegetables. J. Jpn. Soc. Hort. Sci., 67: 1098-1114

López-Marín, J., A. González, F. Pérez-Alfocea, C. Egea-Gilabert and J.A. Fernández, 2013. Grafting is an efficient alternative to shading screens to alleviate thermal stress in greenhouse grown sweet pepper. Sci. Hortic., 149: 39-46

Louws, F.J., C.L. Rivard and C. Kubota, 2010. Grafting fruiting vegetables to manage soil borne pathogens, foliar pathogens, arthropods and weeds. Sci. Hortic., 127: 127-146

Mahmood, A. and R.N. Malik, 2014. Human health risk assessment of heavy metals via consumption of contaminated vegetables collected from different irrigation sources in Lahore, Pakistan. Arab. J. Chem., 7: 91-99

Melnyk, C. W. and E.M. Meyerowitz, 2015. Plant grafting. Curr. Biol., 25 R183-R188

Miles, C., J. Wimer and D. Inglis, 2015. Grafting eggplant and tomato for verticillium wilt resistance. In: Proceeding of the First International Symposium on Vegetable Grafting Z. Bie, Y. Huang, M.A. Nawaz (eds.). Acta Hort., 1086: 113-118

MOF, 2015-2016. Economic Survey of Pakistan. Ministry of Finance, Government of Pakistan http://www.finance.gov.pk/survey/chapters_16/02_Agriculture.pdf. (Accessed on January 23, 2016)
Nawaz, K., A.A. Shahid, M.N. Subhani, W. Anwar and M. Aslam, 2016a. First report of Pythium spinosum causing root rot of chili (Capsicum annuum) in Pakistan. Plant Dis., 100: 526

Nawaz, M.A., L. Wang, Y. Jiao, C. Chen, L. Zhao, M. Mei, Y. Yu, Z. Bie and Y. Huang, 2017. Pumpkin rootstock improves nitrogen use efficiency of watermelon scion by enhancing nutrient uptake, cytokinin content, and expression of nitrate reductase gene. Plant Growth Reg., 82: 233-246

Nawaz, M.A., M. Imtiaz, Q. Kong, F. Cheng, W. Ahmed, Y. Huang and Z. Bie, 2016b. Grafting: a technique to modify ion accumulation in horticultural crops. Front. Plant Sci., 7: 1457

Naz, I., M. Ahmad, S. Alam, M. Tahir and F. Raziq, 2007. Control of root and collar rot disease, a serious threat to chillies production in NWFP. Sarhad J. Agric., 23: 451-453

Noor-ul-Amin, A. Hussain, S. Alamzeb and S. Begum, 2013. Accumulation of heavy metals in edible parts of vegetables irrigated with waste water and their daily intake to adults and children, district Mardan, Pakistan. Food Chem., 136: 1515-1523

Oda, M., 1999. Grafting of vegetables to improve greenhouse production. Food Fert. Technol. Cen. Ext. Bull., 480: 1-11

Oda, M., 2002. Grafting of Vegetable Crops, Vol. 54, pp: 49-72. Scientific report of the graduate school of agriculture and biological sciences, Osaka Prefecture University

Penella, C., M. Landi, L. Guidi, S.G. Nebauer, E. Pellegrini, A.S. Bautista, D. Remorini, C. Nali, S. López-Galarzaa and A. Calatayud, 2016. Salt-tolerant rootstock increases yield of pepper under salinity through maintenance of photosynthetic performance and sinks strength. J. Plant Physiol., 193: 1-11

Penella, C., S.G. Nebauer, A. Quinones, A.S. Bautista, S. López-Galarza and A. Calatayud, 2015. Some rootstocks improve pepper tolerance to mild salinity through ionic regulation. Plant Sci., 230: 12-22

Pulgar, G., G. Villora, D.A. Moreno and L. Romero, 2000. Improving the mineral nutrition in grafted watermelon: nitrogen metabolism. Biol. Plant, 43: 607-609

Raza, A., 2016. The State of Seed in Pakistan. MIT Technology Reviews Pakistan. Available at: http://www.technologyreview.pk/state-seedpakistan/(Accessed on: $23^{\text {rd }}$ May, 2017)

Rivero, R.M., J.M. Ruiz and L. Romero, 2004. Iron metabolism in tomato and watermelon plants: influence of grafting. J. Plant Nutr., 27: 2221-2234

Rouphael, Y., D. Schwarz, A. Krumbein and G. Colla, 2010. Impact of grafting on product quality of fruit vegetables. Sci. Hortic., 127: 172179

Ruiz, J.M., A. Belakbir, I. Lhpez-Cantarero and L. Romero, 1997. Leafmacronutrient content and yield in grafted melon plants. A model to evaluate the influence of rootstock genotype. Sci. Hortic., 71: 227-234

Saeed, A., K. Hayat, A.A. Khan and S. Iqbal, 2007. Heat tolerance studies in tomato(Lycopersicon esculentum Mill.). Int.J.Agric. Biol., 9: 649-652

Saeed, A.F.H. and S.N. Khan, 2010. Postharvest losses of tomato in markets of district Lahore. Mycopath, 8: 97-99

Sakata, Y., M. Sugiyama, T. Ohara and M. Morishita, 2006. Influence of rootstocks on the resistance of grafted cucumber (Cucumis sativus L.) scions to powdery mildew (Podosphaera xanthii U. Braun and N. Shishkoff). J. Jpn. Soc. Hort. Sci., 75: 135-140

Sakata, Y., T. Ohara and M. Sugiyama, 2007. The history and present state of the grafting of cucurbitaceous vegetables in Japan. Acta Hort., 731: $159-170$

Sakata, Y., T. Ohara and M. Sugiyama, 2008. The history of melon and cucumber grafting in Japan. Acta Hort., 767: 217-228

Salehi, R., A. Kashi, J.M. Lee and R. Javanpour, 2014. Mineral concentration, sugar content and yield of Iranian 'Khatooni' melon affected by grafting, pruning and thinning. J. Plant Nutr., 37: 12551268

Sandeep, S., T.R. Sachdev and R. Sachdeva, 2013. Increasing fruit and vegetable consumption: challenges and opportunities. Ind. $J$. Commun. Med., 38: 192-197

Savvas, D., D. Papastavrou, G. Ntatsi, A. Ropokis and C. Olympios, H. Hartmann and D. Schwarz, 2009. Interactive effects of grafting and manganese supply on growth, yield, and nutrient uptake by tomato. HortSci., 44: 1978-1982 
Savvas, D., G. Colla, Y. Rouphael and D. Schwarz, 2010. Amelioration of heavy metal and nutrient stress in fruit vegetables by grafting. Sci. Hortic., 127: 156-161

Savvas, D., G. Ntatsi and P. Barouchas, 2013. Impact of grafting and rootstock genotype on cation uptake by cucumber (Cucumis sativus L.) exposed to Cd or Ni stress. Sci. Hortic., 149: 86-96

Schwarz, D., G.B. Oztekin, Y. Tuzel, B. Bruckner and A. Krumbein, 2013. Rootstocks can enhance tomato growth and quality characteristics at low potassium supply. Sci. Hortic., 149: 70-79

Schwarz, D., Y. Rouphael, G. Colla and J.H. Venema, 2010. Grafting as a tool to improve tolerance of vegetables to abiotic stresses: thermal stress, water stress and organic pollutants. Sci. Hortic., 127: 162-171

Shakeel, Q., N. Javed, Y. Iftikhar, I.U. Haq, S.A. Khan and Z. Ullah, 2012. Association of plant parasitic nematodes with four vegetable crops. Pak. J. Phytopathol., 24:143-148

Shaukat, S., 2014. The Next 10 Years of Tunnel Farming in Pakistan. http://pakagrifarming.blogspot.com/2014/03/109-next-10-yearsof-tunnel-farming-in-pakistan.html (Accessed on January 23, 2017)

Suchoff, D., C. Gunter, J. Schulthesis and F.J. Louws, 2015. On farm grafted tomato trial to manage bacterial wilt. In: Proceeding of the First International Symposium on Vegetable Grafting. Z. Bie, Y. Huang and M.A. Nawaz (eds.). Acta Hort., 1086: 119-127

Treeby, M., H. Marschner and V. Romheld, 1989. Mobilization of iron and other micronutrients cations from a calcerous soil by plantborne, microbial, and synthetic metal chelators. Plant Soil, 114: $217-226$
UN, 2015. United Nations, Department of Economic and Social Affairs. Available http://www.un.org/en/development/desa/news/population/2015report.html. Accessed on $24^{\text {th }}$ May, 2017

Xin, J., B. Huang, J. Yang, Z. Yang, J. Yuan and Y. Mu, 2013. Role of roots in cadmium accumulation of two water spinach cultivars: reciprocal grafting and histochemical experiments. Plant Soil., 366: 425-432

Yamakawa, B., 1983. Grafting. In: Vegetable Handbook, pp: 141-153. Nishi (ed.). Yokendo Book Company, Tokyo, Japan

Yetisir, H., A.E. Özdemir, V. Aras, E. Candır and O. Aslan, 2013. Rootstocks effect on plant nutrition concentration in different organ of grafted watermelon. Agric. Sci., 4: 230-237

Zen, Y.A., Y.L. Zhu, B.J. Huang and L.F. Yang, 2004. Effects of Cucurbita ficifolia as rootstock on growth, fruit setting, disease resistance and leaf nutrient element contents in Cucumis sativus. J. Plant Resour. Environ., 13: 15-19

Zhao, X., Y. Guo, D.J. Huber and J. Lee, 2011. Grafting effects on postharvest ripening and quality of 1-methylcyclopropene-treated muskmelon fruit. Sci. Hortic., 130: 581-587

Zhou, J., H. Wan, S. Qin, J. He, D. Lyu and H. Li, 2016. Net cadmium flux and gene expression in relation to differences in cadmium accumulation and translocation in four apple rootstocks. Environ. Exp. Bot., 130: 95-105

Ziad, M., S. Khalid, W. Shah, A. Naz and Z. Rehman, 2016. Impacts of water logging and salinity on crops production of village Adina, district Swabi. ARPN J. Agric. Biol. Sci., 11: 217-222

(Received 26 January 2017; Accepted 27 May 2017) 